\title{
Research into the Usage of the Word "Otherwise" for Chinese College Students
}

\author{
Xiu Zeng \\ Foreign Language School, Nanchang Normal University, Nanchang, Jiangxi, China
}

\begin{abstract}
The word "otherwise" has long been viewed as a challenge to most Chinese college students, for it often changes in the way that it is used and understood. By taking a careful study of the word itself and the context where the word is used, this paper tries to explore the possible uses and interpretations of the word "otherwise" to help Chinese students better understand it in different contexts, and then to offer the suggested solutions to the improvement in the proper understanding and use of the word.
\end{abstract}

Index Terms —otherwise, analysis, usage

\section{INTRODUCTION}

Reading, like the other basic language skills in English learning, plays an important role in daily communication in social life. It is usually considered to be a sign of one's language competence and comprehensive power (Zeng, 2018). But for most Chinese learners, English reading is still a great challenge. Students at university level still suffer from a limited lexicon and weak language foundation though they work hard enough and do well in reading exams (Zeng, 2018).

For majority of Chinese students, they begin to learn English in high school, taking it as a compulsory course in university. In spite of the fact that much time and efforts have been devoted to English learning in their secondary school(Zeng, 2018), they still cannot make a good sense of some difficult words, less to say to make proper use of them to express themselves in communication.

The word "otherwise" is one of such difficult words for most Chinese students in their daily reading. "Otherwise" is a common word in English vocabulary, but it is also the word that can easily confuse and overwhelm Chinese students in their reading comprehension. In most cases, it is an ordinary conjunction, adjective or adverb and is interpreted as "if not, or else", but in different contexts, it can be changed or extended much in its basic sense and function, it changes so much as to puzzle or hinder students, or as to disable them to go on with reading with interest.

\section{ANALYSIS OF THE USAGE OF THE WORD “OTHERWISE”}

For the above-mentioned reasons, I will first go back to its origin, then move into its makeup, and last offer possible solutions to go further into its usage. "Otherwise" dates from old English "on othre wisan"(David, 1980) (used in the $14^{\text {th }}$ or $15^{\text {th }}$ century), today it means "in another manner" (David, 1980) in a modern sense. In its word composition, "other-" has a sense of being "different", different from what has been talked about, "-wise" is a suffix of a word, referring to "manner or aspect", for example, "likewise", "clockwise", or "dropwise", etc. On the basis of its composition and contexts, this paper will aim to explore its expanded senses, and will guide Chinese students how to understand and use it properly.

\section{A. "Otherwise" Is Used in Different Ways}

"Otherwise" can be used in different ways in different contexts, it can be a conjunction, adjective and adverb in different patterns of sentences, semantically taken as “ or, else , if not". In different circumstances, it can be interpreted and used in the following ways:

1. "Otherwise" is a conjunction, interpreted to be "or, else , if not"

We will hurry up, otherwise we may be late for school.

我们得抓紧时间, 要不上学迟到了。

Save some money for future, otherwise you will regret it.

为将来存点钱, 要不然你会后悔的。

I felt ill the other day, otherwise I would have gone to the meeting.

前几天我生病了, 否则我会去参会的。

Drivers have to follow traffic regulations, otherwise they will be punished.

司机必须遵守交通规则, 否则将受到惩罚。

2. "Otherwise" is an adjective, read as "not as supposed or in a different state"

The story sounds reasonable, but the truth is quite otherwise.

故事听着有道理, 但事实真相与此大相径庭。 
She is quite well in health though she looks much otherwise.

她身体其实很好, 尽管看上去欠佳。

Some are wise, some are otherwise.

有些人聪明, 有些人则愚蚌。

We welcome any comments from viewers, favorable or otherwise.

我们欢迎观众提出意见, 赞成的或批评的都行。

I fear she will be superstitious. Indeed, how could she be otherwise?

我担心她会相信迷信。确实, 她怎么可能不信呢?

3. "Otherwise" is an adverb

a. It can be interpreted to be "differently, in another way"

We believe he is selfish, but he evidently thinks otherwise.

我们认为他很自私, 但他显然不这样认为。

There is no dream you cannot achieve. Never let anyone tell you otherwise.

没有你不能实现的梦想。决不让别人告诉你, 你的梦想无法实现。

If it ends well, it means both of you want more. If it ends otherwise, the next thing to do is to wave goodbye to each other.

如果结局好, 说明你们两人都想进一步发展.如果结局不好, 接下来就会分手。

Only by saving will you have money in the bank or otherwise invested.

只有节省你才会有钱存在银行里或以其他方式投资。

We will get there somehow, by boat or otherwise.

坐船或以其他交通工具，我们将会想办法到达那儿，

The government claims that the economy is improving, but this survey suggests otherwise.

政府宣传经济形势在好转，但这项调查却有不同的结果。

Here are two difficult paragraphs with "otherwise" in them

First, the Handlins cannot adequately demonstrate that the White servant's position was improving during and after the 1660's; several acts of the Maryland and Virginia legislatures indicate otherwise (2015, GRE).

首先, 汉德林夫妇无法充分证明白人佣人的地位在十七世纪六十年代期间得到了提升; 马里兰州和弗吉尼亚 州的立法机构颁布的几项法案表明情况恰恰相反 (2015, GRE)。

In physics, subject and object were supposed to be entirely distinct, so that a description of any part of the universe would be independent of the observer. The quantum theory, however, suggests otherwise, for every observation involves the passage of a complete quantum from the object to the subject, and it now appears that this passage constitutes an important coupling between observer and the observed (2015, GRE).

在物理学中, 主体和客体被假定为绝然互不相关的, 因此, 对宇宙的任何一个部分进行描述, 终将独立于观 察者。然则, 量子理论暗示情形恰恰相反, 因为每一项观察都涉及一个完整的量子从客体到主体的过渡, 而现 在看来，这一过渡构成了观察者与被观察物之间的一种重要的结合（2015, GRE）。

b. It may be interpreted to be "in the other aspects", often preceded by "but"

Dad still has a bit cold, but otherwise all are well.

爸爸还有点感冒, 但其他方面都好。

The food ran out early, but otherwise the party was a success.

食物很快被吃光了, 但聚会在其他方面办得很成功。

He is noisy, but otherwise a nice boy.

他爱吵闹，除此之外，倒是个好孩子。

The girl is a little dirty, but not otherwise contemptible.

这孩子就是有点脏, 其他倒没什么不好。

The cousins are alike in age, but otherwise as different as day and night.

堂兄弟年龄相近，其他方面相差甚远。

\section{B. “Otherwise” Can Help to Build English Subjunctive Mood}

"Otherwise", to most Chinese students, poses much more challenge when it appears in the English subjunctive mood. It usually refers to something that did not happen, or suggests a different case or situation. In this sense, "otherwise" helps to build a special kind of subjunctive mood. The following sentences will be the illustrations of the usage of "otherwise" in a different sentence pattern.

1. "Otherwise" is involved in short phrases

The much admired writer enjoyed a successful career, but later caught a serious disease and lived an otherwise happy life.

这位令人钦佩的作家事业有成, 但后来患上严重疾病, 要不然, 可以过着幸福的生活。

The coloured lights in the trees have lent bright colors to an otherwise dull city. 
树上的彩灯为这个(要不然)乏味的城市增添了明亮色彩。

Hemingway welcomed his discovery of a worthwhile cause because it could give significance to an otherwise meaningless death.

海明威很高兴发现了一项有价值的事业（写作）, 因为它可能赋予了死亡意义, 否则, 他的去世则可能没有 启示或警世意义。

The ability to conceal themselves by camouflage enables some otherwise defenseless animals to survive.

通过伪装而隐藏自己的能力帮助一些 (如果无法伪装隐藏) 则毫无自卫能力的动物生存。

His refusal to help his brother could well result in the failure of business that will otherwise be very successful.

他拒绝帮助他弟弟, 很可能导致生意失败, 否则, 他弟弟的生意可能会很好的。

Appointing one woman to the otherwise all-male staff could look like tokenism.

给原本清一色的男职员队伍增派一位女性会显得是装点门面。

2. "Otherwise" is included in the subjunctive mood sentences

Well-educated people make more money than they would otherwise do.

接受过良好教育的人比他们（没接受教育时），有更高工作收入。

In a crisis people are more on edge and agitated than they would otherwise be.

在面对危机之时, 人们比平时（没有危机的时候）更加焦虑不安

Trade makes it possible for surplus manufactured goods to be traded abroad for the agriculture products that would otherwise be lacking.

贸易有可能将国内剩余产品销售到海外以换取农产品, 否则, 国内会缺乏农产品。This activity can help you release thoughts that might otherwise prevent you from getting needed sleep.

这项活动有助于你放弃一些意念, 要不然, 这些意念可能会妨碍你获得必要睡眠。Their suggestion has made the design better than it would otherwise have been.

他们的建议使这项设计比原本 (如果未采纳他们的建议) 更好。

The student went through the paper, finding some mistakes that might otherwise have been ignored.

学生检查了试卷, 发现了一些否则可能被忽略的错误。

He warned me of the danger that I would otherwise have neglected.

他提醒了我, 要不然, 我会忽视危险。

Quality education also free communities and countries, allowing them to leap forward into periods of wealth and social unity that otherwise would not be possible (2015, GRE).

素质教育同样解放了社会和国家, 使其跨越进入富裕和社会统一期, 否则, 这一切就不可能实现。

Because of the differences in the manner of expression between Chinese and English, the way that "otherwise" is used in the English subjunctive mood often puzzles students so much that they either misunderstand it or fail to get it at all. The proper solution to it is to explore its possible extended meanings on the basis of the very context and its core sense.

\section{The Common Set Phrases with "Otherwise"}

"Otherwise" itself is a difficult word, when it is used together with another word, it poses more challenge to Chinese students, for the phrase can not be interpreted word by word. Further, there are no Chinese words that are combined or built in the similar way.

1. "Otherwise than" is decoded to be "different from"

Our life cannot be otherwise than happy.

我们的生活一定会幸福的。

How could it be otherwise than frightful?

这怎么会不吓人呢?

No person shall be tried or punished otherwise than by a law court in accordance with the procedure prescribed by law (2015,GRE).

对人进行审判和惩处只能由法院依照法律规定的程序来进行。

2. "And otherwise" is interpreted to be “other activities"

During break in classroom, the children are singing, dancing, drawing and otherwise.

课间, 孩子们在唱歌、跳舞、画画及开展其他活动。

You can take it, leave it and otherwise.

你可以取走它，留下它以及用其他方式处理。

3. "Or otherwise" is interpreted to be "completely different or opposite"

In holiday, we can choose to be busy or otherwise.

假期我们可以找事做或闲着。

Married mothers or otherwise are welcome to our meeting.

妈妈们无论婚否, 都欢迎参会。

He does not mind whether it is moral or otherwise. 
道德与否他不在乎。

I must emphasize that I am not making a plea, disguised or otherwise.

我必须澄清我不是在作辩护，无论伪装还是真实的

He didn't want company, talkative or otherwise.

他不愿有人陪伴, 无论同伴是否健谈。

\section{Suggested AcCesses to the MeANing AND Uses of "Otherwise”}

In terms of linguistic competence, poor command of vocabulary and inability to understand it properly may be one of the major obstacles in the way to improve English for Chinese college students (Zeng, 2018). It is important to recognize that students do not learn from the first presentation of the new language items alone. They need to be introduced or even reintroduced to the new items, that is, more often a new word is included in the reading or daily communication, more likely the reader will be familiar with it and understand it better, until they can have a full command of what they have learnt, until they can produce them readily when required (Zeng, 2018).

To reach this goal, students might be often asked to practise a certain number of language models, such as word substitution, sentence patterns, structure of paragraphs, etc. In many English textbooks, ,for example, New College English, there are always such items of exercise as " replace A with B", "reorganize the following sentences after the models" or "compose a paragraph on the provided structure" (Yang, 2002), etc. The repeated phrases and structures with the new learned words in them are usually the most often used ones. To be familiar with them is really a great advantage for students to be fluent users of English (2018, Zeng).

It is no exception with the learning and practice of "otherwise", that is to say, the above-suggested steps can be applied to the mastery of the word "otherwise", but it will be done under the condition that the other means of word study may be included and tried, for example,

\section{A. Word Analysis}

It is known that many words in English have been formed by constantly combining parts of old English, Greek, and Latin words. One can break down a word by looking for prefixes, suffixes, and root words. If you know what these word parts mean, then you can often figure out what a newly-combined word mean, especially with the help of the context. By teaching Chinese students the skills to break up different parts of a word, we may provide them with a useful tool so they won't necessarily have to run to a dictionary to consult it. They can also get a hint about what these words possibly mean at the time they first meet them.

For example, subscribe, subscribe $=($ prefix $)$ sub $+($ stem $)$ scribe

sub- $=$ under; - scrib- $=$ write. It can be interpreted to be: write under

scientist, $\quad$ sci-(en) $=$ know $($ Latin $), \quad$-ist=one who

It can be interpreted to be : a man who knows (much)

otherwise, other-=different, -wise=way

It can be interpreted to be: (in) different way

\section{B. Context Clues and Mental Association}

Using context clues is one of the proper ways to discover what an unfamiliar or difficult word means. Before you can understand what you read, you have to understand the most words you are reading. By looking carefully at the other words in the sentence or by focusing on the sentences around it, and seeing how the new word fits in, you can work better at determining what the new word possibly means. Often an author includes hints, or clues to help the reader expand vocabulary from its core meaning and help them grasp what the specific words or sentences mean, take the following sentences for example:

The story sounds reasonable, but the truth is quite otherwise. (1.2)

I fear she will be superstitious. Indeed, how could she be otherwise? (1.2)

Here, "reasonable" and "superstitious" are the useful clues for the reader to figure out the meaning of the two "otherwise" in the above sentences, the first means "not reasonable" and the second suggests "not superstitious".

More examples:

Dad still has a bit cold, but otherwise all are well. (1.3.2)

The food ran out early, but otherwise the party was a success. (1.3.2)

Here, "otherwise" in the first sentence refers to "in the other aspects except the fact that Dad still has a bit cold".

Likewise, in the second sentence, "otherwise" refers to "in the other aspects except the fact that the food ran out early".

Without the clear statement of the fact in the other part of the sentence, then it will be quite hard for Chinese students to follow the word "otherwise" and even the whole sentences.

In addition, mental association is much required in the grasp of the meaning of "otherwise", for the way it changes in its usage often goes a little beyond the comprehension of Chinese students, who are unable to find the similar sentence structure in the learning of their own language, for example, 
The much admired writer enjoyed a successful career, but later caught a serious disease and lived an otherwise happy life. (2.1)

Here, the phrase "lived an otherwise happy life" means that "the writer would live a happy life in a different case (he did not catch a serious disease).

The ability to conceal themselves by camouflage enables some otherwise defenseless animals to survive. (2.1)

Here, the phrase "some otherwise defenseless animals" means that "some animals would be defenseless if they were unable to conceal themselves by camouflage"

Therefore, no matter in what way "otherwise" appears in a sentence or in what collocation it is used with other words, the right way to understand it is to expand it from its core sense "in a different way", "different from what has been said or stated", in this way, the words before it or after it are of great help so that the context can not be neglected or missed.

\section{CONCLUSION}

To sum up, learning to read and interpret words is a long, complex and creative process in which a series of language practices and the related activities are involved and interrelated (Zeng, 2018). On the one hand, well-targeted and extended reading practice helps Chinese students make proper and frequent improvements in reading abilities, on the other hand, constant exposure to different sources of texts through different designs works to improve the mind of students (Zeng, 2018). As we know, for most Chinese college students, vocabulary is often more important and challenging than grammar, as D. A. Wilkins (1972) said "Without grammar very little can be conveyed; without vocabulary nothing can be conveyed."

Vocabulary is very infinite and words are often more complex than they appear to be, for words are not isolated from but associated with a certain type of context or situation, thus they behave differently in different contexts (Zeng, 2018). Therefore, special attention has to be directed to the expanded meaning, to the usage of words and to their collocation in text reading.

Further, it is important to recognize that students have to be exposed to the difficult or strange words in different contexts as much as possible, in this way they may be well impressed with its central meaning and with the established ways that it is used. If English teachers have a deep understanding of the interrelation between word reading and the contributing factors (Zeng, 2018), if English teachers place equal stresses on the words themselves, on the contexts and on the practice of their uses, if English teachers integrate word reading into the whole process of teaching, then all the efforts made by teachers and students will be much rewarded (Zeng, 2018).

\section{ACKNOWLEDGMENTS}

This paper is funded by 11531 project of Nanchang Normal University

\section{REFERENCES}

[1] David, A.Wilkins. (1972). Linguistics in Language Teaching. Cambridge: MA: MIT Press.

[2] David, B. (1980). Webster's New World Dictionary. Cleveland, Ohio: William Collins Publishers.

[3] http://www.kekenet.com/GRE/201504/367423.shtml.

[4] http://www.kekenet.com/GRE/201504/370353.shtml.

[5] L.M.Yang. ( 2002). New College English. Shanghai: Shanghai Foreign Language Education Press.

[6] Xiu Zeng. (2018). A Study on the Improvement of English Writing Competence for College Students. Journal of Language Teaching and Research, 9, 1344-1348.

Xiu Zeng is an English teacher in Foreign Language School, Nanchang Normal University, Nanchang, Jiangxi, China. She has received her M.A in English language and literature from Jiangxi University (Nanchang University thus named today), her main interest is English teaching, English and America literature instruction. She has done some pieces of research in the instruction of English learning skills. 